Sains Malaysiana 49(11)(2020): 2667-2677

http://dx.doi.org/10.17576/jsm-2020-4911-06

\title{
Design, Synthesis and Biological Evaluation of Aminoalkylated Chalcones as Antimalarial Agent
}

(Reka Bentuk, Sintesis dan Penilaian Biologi ke atas Aminoteralkil Kalkon sebagai Agen Antimalaria)

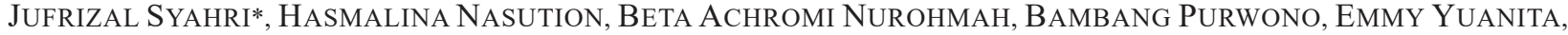 \\ NUR HANIS ZAKARIA \& NURUL IZZATY HASSAN
}

\begin{abstract}
Aminoalkylated chalcone compounds (4a-4c) have been designed using Quantitative Structure-Activity Relationship (QSAR) analysis, synthesized and evaluated for their in vitro antimalarial activity. The best QSAR model obtained was $\log I C_{50}=705.132(q C 7)-65.573(q C 3)-24.845(q C 4)-4.634(q C 13)-220.479$ and statistical analysis showed $R^{2}$ of 0.937, suggesting that the QSAR model was able to predict the actual antimalarial activity by $93.7 \%$ accuracy. The addition of secondary amines to the chalcone compounds was successfully carried out using the Mannich reaction, which was confirmed by spectroscopic analysis. The in vitro antimalarial activity of the synthesized compounds were screened against the 3D7 strain of Plasmodium falciparum (CQ sensitive). All of the compounds exhibited strong activity with $I_{50}$ values ranging from $0.54 \pm 0.649$ to $1.12 \pm 0.369 \mu \mathrm{M}$. The molecular docking studies investigated interactions of the prepared compounds to the binding site of wild-type Plasmodium falciparum dihydrofolate reductasethymidylate synthase (Pf-DHFR-TS) (PDB ID: IJ3I) and quadruple mutant Pf-DHFR-TS (PDB ID: IJ3K). Some hydrogen bond and $\pi-\pi$ interactions were observed with the side chain of Ala16, Asp54, Cys 15, Leu164, Tyr170, and Met55 in both the wild and mutant Pf-DHFR types. It has also been found that all the tested compounds were obeyed the Lipinski's rule. This study proposed that compound $4 b$ can be developed as the new lead of the antimalarial agent.
\end{abstract}

Keywords: Antimalarial; chalcone; Mannich reaction; molecular docking; QSAR

ABSTRAK

Sebatian aminoteralkil kalkon (4a-4c) telah direka bentuk menggunakan analisis Hubungan Struktur-Aktiviti Kuantitatif (QSAR) telah disintesis dan dinilai untuk aktiviti antimalaria secara in vitro. Model QSAR terbaik yang diperoleh adalah $\log I C_{50}=705.132$ (qC7)-65.573 (qC3)-24.845 (qC4)-4.634 (qC13)-220.479 dan analisis statistik menunjukkan $R^{2}$ sebanyak 0.937, seterusnya mencadangkan bahawa model QSAR ini berupaya untuk meramalkan aktiviti antimalaria sebenar dengan ketepatan 93.7\%. Penambahan amina sekunder telah dijalankan menggunakan tindak balas Mannich dan disahkan melalui analisis spektroskopi. Kesemua sebatian disaring menentang strain Klorokuina-sensitif (3D7) Plasmodium falciparum. Semua sebatian menunjukkan aktiviti baik dengan nilai IC ${ }_{50}$ antara $0.54 \pm 0.649$ sehingga $1.12 \pm 0.369 \mu$ M. Interaksi sebatian ini juga dikaji melalui kajian dok pada tapak pengikatan protein jenis liar Pf-DHFR-TS (PDB ID: IJ3I) dan mutan Pf-DHFR-TS (PDB ID: IJ3K). Ikatan hidrogen dan interaksi $\pi-\pi$ sebatian dengan rantai sisi asid amino Ala16, Asp54, Cys 15, Leu164, Tyr170 dan Met55 jelas diperhatikan pada kedua-dua protein tersebut. Sebatian yang dikaji ini juga didapati mematuhi peraturan Lipinski. Potensi aktiviti antimalaria yang ditunjukkan oleh sebatian 4 b mampu dibangunkan sebagai sebatian utama.

Kata kunci: Antimalaria; kajian dok; kalkon; QSAR; tindak balas Mannich

\section{INTRODUCTION}

Malaria has become the target of eradication in 2050, as mentioned in the Global Malaria Programme (GMP) by WHO. In 2018, malaria cases were reported up to 228 million cases worldwide, with 405 thousand mortalities (WHO 2018). The resistance of the Plasmodium parasite to the antimalarial drugs, such as chloroquine (CQ) and artemisinin, is pointed out as the main factor that leads to the high mortality cases (Ashley et al. 2014; Sibley 2015). Some efforts have been made to decrease the fatality rate by exploring traditional therapies (Chen et al. 1994), developing combination drugs (Bhasin \& Nair 2003), 
and also introducing the malaria vaccine (WHO 2019). However, these attempts do not show any significant result. For that reason, preventing the resistance of the Plasmodium parasite is needed to actualize the zero cases in 2050 by discovering new antimalarial drugs that are more effective and efficient than chloroquine or artemisinin.

Chalcone is one of the natural compounds that has been reported to have many bioactivities such as anticancer (Elkhalifa et al. 2020; Yang et al. 2019; Zhang et al. 2019), anti-inflammatory (Ur-Rashid et al. 2019; Wang et al. 2019a), antibacterial (Dan \& Dai 2020; Khan et al. 2019), antioxidants (Wang et al. 2019b), antidiabetic (Rammohana et al. 2020; Shin et al. 2018), antivascular (Tuncel et al. 2013), antigiardial (Cáceres-Castillo et al. 2020), antileukemia (Quaglio et al. 2019), and antimalarial (Jyoti et al. 2019; Reeta et al. 2019; Wilhelm et al. 2015). It has been reported that chalcone compounds with some functional groups such as prenyl and allyl (Syahri et al. 2017b), hydroxyl and methoxy (Syahri et al. 2017a) were active as an antimalarial agent. However, their activity was relatively weak compared with chloroquine as the commercial drug.

Chloroquine and quinine are known as antimalarial drugs bearing amines group. It has been suggested that an amine functional group plays a vital role in the antimalarial activity. According to Suwito et al. (2014) amine groups could form electrostatic interactions with amino acids from the protein of Plasmodium. The presence of the electrostatic interaction could disrupt the synthesis of protein so that the Plasmodium parasite could die. Thus, the substitution of secondary amine to the aromatic ring of chalcone is expected could give better antimalarial activity.

A theoretical study approach using Quantitative Structure-Activity Relationship (QSAR) analysis and molecular docking can predict the best biological activities of compounds. Currently, the theoretical approach by computational chemistry is paramount in the development of new drugs. This method can build a correlation between chemical structures and biological activities in a mathematical model, which can be statistically validated so that it can predict the bioactivities of a compound very well (Golbraikh 2003).

In this work, we reported the design of aminoalkylated chalcone using QSAR analysis to recommend some compounds with better antimalarial activity. Furthermore, the proposed compounds were then synthesized through the Mannich reaction method to add amine groups, such as morpholine, piperidine, and diethylamine. Evaluation of their in vitro antimalarial activity was carried out against CQ-sensitive strain (3D7) of P. falciparum to confirm the QSAR analysis result. Molecular docking was performed to predict the interaction of the prepared compounds to the protein of CQ-sensitive dihydrofolate reductases-thymidylate synthase (PfDHFR-TS) (PDB ID: 1J3I) and CQ-resistance $P f$ DHFR-TS (PDB ID: 1J3K).

\section{MATERIALS AND METHODS}

Chemicals used in the synthesis of chalcone compounds were 4-chloroacetophenone, vanillin (4-hydroxy-3methoxy benzaldehyde), sodium hydroxide, ethanol, hydrochloric acid, formaldehyde, morpholine, piperidine, diethylamine, hexane, ethyl acetate, and silica gel $\left(60 \mathrm{GF}_{254}\right)$ for column chromatography and thin-layer chromatography (TLC). All chemicals for the synthesis were purchased from Aldrich, Acros, and Merck, and used without further purification otherwise stated. All the solvents used in the synthesis were in analysis and synthesis grade. The melting point of the synthesized compounds was determined using Electrothermal 9100 at $10{ }^{\circ} \mathrm{C} / \mathrm{min}$ temperature gradient (uncorrected). Mass spectra (MS) were recorded on Shimadzu-QP 2010S, and the proton $\left({ }^{1} \mathrm{H}\right)-$ and carbon $\left({ }^{13} \mathrm{C}\right)-\mathrm{NMR}$ spectra were recorded on a JEOL $500 \mathrm{MHz}$ spectrometer with tetramethylsilane (TMS) as the internal standard.

\section{COMPUTATIONAL WORK}

The computational work was performed in a $\mathrm{PC}$ with a processor of Intel ${ }^{\circledR}$ Core $^{\mathrm{TM}}$ i7 CPU M $3504.54 \mathrm{GHz}$; RAM $8.00 \mathrm{~GB}$. Gaussian 09 software was used to execute the quantum mechanical calculations. The multiple linear regression analysis using SPSS statistics 23.0 was employed to evaluate the obtained correlation models. Meanwhile, molecular docking was carried out using Discovery Studio 2016 (Accelrys, San Diego, USA).

\section{QSAR ANALYSIS}

The data set used in the QSAR analysis was 25 (twentyfive) aminoalkylated chalcone derivatives from the previously reported work (Wilhelm et al. 2015). Only aminoalkylated chalcone compounds that were reported to be active as antimalarial to D10 strains were used as a data set. From this data set, the nineteen compounds were used as the training set (internal evaluation) and six of them as the test set (external evaluation) (Table 2). The data set was divided by considering the antimalarial activity $\left(\mathrm{IC}_{50}\right)$ of the test set compounds were in the range of the maximum and minimum of $\mathrm{IC}_{50}$ value of the training set (Jain et al. 2012). The in vitro antimalarial activity was expressed as the Inhibition Concentration values $\left[\mathrm{IC}_{50}(\mu \mathrm{g} / \mathrm{mL})\right]$ and then converted to the logarithmic scale $p \mathrm{IC}_{50}\left[p \mathrm{IC}_{50}=\log \mathrm{IC}_{50}\right]$ and used as dependent variables in QSAR analysis. 
Geometry optimization of the tested compounds was performed with the semi-empirical AM1 method in the Gaussian 09 software. A correlation analysis was performed in SPSS 23.0 software by taking each electronic descriptor as an independent variable and $p \mathrm{IC}_{50}$ as a dependent variable to select the predominant descriptors that affecting the antimalarial activity (Syahri et al. 2016). The regression coefficients values were estimated by applying the least square curve fitting method. The best QSAR model was chosen based on some statistical parameters, i.e., correlation coefficients $\left(\mathrm{r}^{2}\right)$, standard estimation of error (SEE), F-ratio between the prediction $\left(\mathrm{F}_{\text {calc }}\right)$ and observation $\left(\mathrm{F}_{\text {table }}\right)$ activity $\left(\mathrm{F}_{\text {calc }} /\right.$ $\mathrm{F}_{\mathrm{tab}}$ ), and predictive residual sum of square (PRESS) value (Frimayanti et al. 2011; Modak et al. 2013; Motta et al. 2011).

\section{GENERAL PROCEDURE FOR THE SYNTHESIS OF AMINOALKYLATED CHALCONE (4A-4C)}

Chalcone derivatives 3 was synthesized through the Claisen-Schmidt condensation method (Scheme 1). The<smiles>[R]Cc1cc(/C=C/C(=O)c2ccc(Cl)cc2)cc(OC)c1O</smiles>

SCHEME 1. Reagents and conditions of synthesis: (i) sodium hydroxide (40\%), ethanol, stir at room temperature overnight; (ii) secondary amine ( $\mathrm{R}=$ morpholine, piperidine, diethylamine), formaldehyde, ethanol, stir overnight

mixture of 4-chloroacetophenone $(1 \mathrm{~mol})$ and vanillin (1 mol) was dissolved in ethanol $(75 \mathrm{~mL})$, and sodium hydroxide $(40 \%)$ was then slowly added while stirring. The reaction was continued at room temperature overnight, and it was stopped when all the starting material has been consumed (monitored using TLC). The reaction mixture was then acidified using $\mathrm{HCl}$ solution (2 M), and the precipitate obtained was filtered and washed using distilled water. Purification of the product was carried out using silica gel column chromatography with hexane: ethyl acetate as an eluent mixture (10-50\% gradient of ethyl acetate).

Synthesis of aminoalkylated chalcone $4 a-4 c$ was carried out using the Mannich reaction method. The mixture of chalcone 3 (30 $\mathrm{mmol})$, formaldehyde (30 $\mathrm{mmol})$, and respective secondary amines $(30 \mathrm{mmol})$ was added in $75 \mathrm{~mL}$ of ethanol (Scheme 1) and refluxed for $24 \mathrm{~h}$. After the reaction was completed (monitored using TLC), the solvent was evaporated under reduced pressure, and the precipitate obtained was purified using silica gel column chromatography with a mixture of hexane: ethyl acetate as eluent (20-80\% gradient of ethyl acetate).

SYNTHESIS OF (E)-1-(4-CHLOROPHENYL)-3-(4-HYDROXY3-METHOXY-5-(MORPHOLINOMETHYL)PHENYL)-PROP-2EN-1-ONE (4A)

Yellow crystals, yield $80 \%$, m.p. $151-152{ }^{\circ} \mathrm{C}$; GC-MS $\left(\mathrm{C}_{21} \mathrm{H}_{22} \mathrm{ClNO}_{4}\right) ;[\mathrm{M}]^{+} 387 .{ }^{1} \mathrm{H}-\mathrm{NMR}(500 \mathrm{MHz}$, acetone-d $)$ $\delta(\mathrm{ppm}): 2.56(\mathrm{t}, 4 \mathrm{H}) ; 3.70(\mathrm{t}, 4 \mathrm{H}) ; 3.77(\mathrm{~s}, 2 \mathrm{H}) ; 3.89(\mathrm{~s}$, $3 \mathrm{H}) ; 7.20(\mathrm{~s}, 1 \mathrm{H}) ; 7.43(\mathrm{~s}, 1 \mathrm{H}) ; 7.56(\mathrm{~J}=8.5 \mathrm{~Hz}, 1 \mathrm{H}) ; 7.71$ (d, J = 15.5 Hz, 1H); 7.74 (d, J = 15.5 Hz, 1H); 8.12 (d, J $=8.5 \mathrm{~Hz}, 2 \mathrm{H}) ; .{ }^{13} \mathrm{C}-\mathrm{NMR}\left(125 \mathrm{MHz}\right.$, acetone- $\left.\mathrm{d}_{6}\right) \delta(\mathrm{ppm})$ : 52.99. 56.19; 61.51; 66.85; 110.54; 118.91; 121.05; 122.97; $126.14 ; 129.03 ; 129.99 ; 136.98 ; 139.07 ; 145.89 ; 148.51$; $150.34 ; 189.29$.

SYNTHESIS OF (E)-1-(4-CHLOROPHENYL)-3-(4-HYDROXY3-METHOXY-5-(PIPERIDIN-1-YLMETHYL)PHENYL)-PROP2-EN-1-ONE (4B)

Yellow crystals, yield $75 \%$, m.p. $150-151{ }^{\circ} \mathrm{C}$; GC-MS $\left(\mathrm{C}_{22} \mathrm{H}_{24} \mathrm{ClNO}_{3}\right) ;[\mathrm{M}]^{+}$385. ${ }^{1} \mathrm{H}-\mathrm{NMR}\left(500 \mathrm{MHz}\right.$, acetone-d $\left.\mathrm{d}_{6}\right)$ $\delta$ (ppm): $1.13(\mathrm{~m}, 6 \mathrm{H}) ; 2.67(\mathrm{~m}, 4 \mathrm{H}) ; 3.87(\mathrm{~s}, 2 \mathrm{H}) ; 3.88(\mathrm{~s}$, $3 \mathrm{H}) ; 7.18(\mathrm{~s}, 1 \mathrm{H}) ; 7.41(\mathrm{~s}, 1 \mathrm{H}) ; 7.58(\mathrm{~d}, \mathrm{~J}=8.5 \mathrm{~Hz}, 2 \mathrm{H})$; $7.71(\mathrm{~d}, \mathrm{~J}=15.5 \mathrm{~Hz}, 1 \mathrm{H}) ; 7.75(\mathrm{~d}, \mathrm{~J}=15.5 \mathrm{~Hz}, 1 \mathrm{H}) ; 8.13$ (d, J $=8.5 \mathrm{~Hz}, 2 \mathrm{H}) .{ }^{13} \mathrm{C}-\mathrm{NMR}\left(125 \mathrm{MHz}\right.$, acetone-d $\left.\mathrm{d}_{6}\right) \delta$ (ppm) 23.96; 25.88; 53.98; 56.15; 61.82; 110.20; 118.46; $121.72 ; 122.90 ; 125.50 ; 128.99 ; 129.98 ; 137.00 ; 138.96$; $146.26 ; 148.49 ; 151.44 ; 189.37$.

\section{SYNTHESIS OF (E)-1-(4-CHLOROPHENYL)-3-(3- ((DIETHYLAMINO)METHYL)-4-HYDROXY-5- METHOXYPHENYL)PROP-2-EN-1-ONE (4C)}

Yellow crystals, yield 70\%, m.p. 84-85 ${ }^{\circ} \mathrm{C}$; GC-MS $\left(\mathrm{C}_{21} \mathrm{H}_{24} \mathrm{ClNO}_{3}\right) ;[\mathrm{M}]^{+}$373. ${ }^{1} \mathrm{H}-\mathrm{NMR}\left(500 \mathrm{MHz}\right.$, acetone- $\left.\mathrm{d}_{6}\right)$ $\delta(\mathrm{ppm}): 1.63(\mathrm{~m}, 6 \mathrm{H}) ; 2.54(\mathrm{~m}, 4 \mathrm{H}) ; 3.75(\mathrm{~s}, 2 \mathrm{H}) ; 3.87$ (s, $3 \mathrm{H}) ; 7.14$ (s, 1H); 7.40 (s, 1H); 7.57 (d, J = 8.5 Hz, 2H); $7.69(\mathrm{~d}, \mathrm{~J}=15.5 \mathrm{~Hz}, 1 \mathrm{H}) ; 7.73(\mathrm{~d}, \mathrm{~J}=15.5 \mathrm{~Hz}, 1 \mathrm{H}) ; 8.11$ $(\mathrm{d}, \mathrm{J}=8.4 \mathrm{~Hz}, 2 \mathrm{H}) .{ }^{13} \mathrm{C}-\mathrm{NMR}\left(125 \mathrm{MHz}\right.$, acetone- $\left.\mathrm{d}_{6}\right) \delta$ (ppm): 25.88; 53.98; 56.14; 61.82; 110.19; 118.45; 121.72; 
$122.00 ; 125.49 ; 128.98 ; 129.98 ; 137.09 ; 138.95 ; 146.26$; $148.49 ; 151.44 ; 189.36$.

ANTIMALARIAL ACTIVITY

An in vitro antimalarial activity of the prepared compounds was evaluated against CQ-sensitive strain (3D7) of Plasmodium falciparum according to the procedure by Rieckmann et al. (1978) with some modifications (Syahri et al. 2017). The prepared compounds were dissolved in DMSO and prepared in a series of concentrations (100.00, $10.00,1.00,0.10$, and $0.01 \mu \mathrm{g} / \mathrm{mL})$ in the RPMI- 1640 culture medium. In this work, chloroquine-diphosphate was employed as a reference drug. For the assessment of antimalarial activity, $\pm 1 \%$ parasitemia and $5 \%$ hematocrit was dispensed in 96 well plates followed by the addition of the tested compounds. The plates were incubated at $37{ }^{\circ} \mathrm{C}$ for $48 \mathrm{~h}$ and stained in $20 \%$ Giemsa dyes solution. The percentage inhibition of $P$. falciparum growth and the parasitemia percentage was calculated from the number of infected erythrocytes for every 1000 erythrocytes on a Giemsa-stained thin blood smear. The $\mathrm{IC}_{50}$ values were determined by Probit log analysis.

\section{MOLECULAR DOCKING}

Molecular docking was performed by following the standard docking protocol with CDOCKER method from Discovery Studio software. Molecular docking was carried out toward protein of CQ-sensitive $P f$-DHFR-TS with PDB ID of IJ3I (resolution of $2.33 \AA$ ) and CQresistant $P f$-DHFR-TS with PDB ID of IJ3K (resolution of $2.10 \AA$ ) (Yuvaniyama et al. 2003). The interactions were observed in a grid map with a grid box size of 28.567944; 5.858250; and 59.659172 (X, Y, Z) for $1 \mathrm{~J} 3 \mathrm{I}$ (radius 10 $\AA$ ), while $28.855583 ; 6.126375$; and 60.192417 for protein $1 \mathrm{~J} 3 \mathrm{~K}$ (radius $8.793 \AA$ ). Proteins were prepared in Discovery Studio software by removing co-crystal ligands from the structure, adding hydrogen atoms, and adjusting the ionizable amino acids (residues) at $\mathrm{pH}$ 7.4 (default protonation). The ligands were predisposed according to the standard docking protocol in Discovery Studio software to build 3-dimensional geometrics and to minimize the energy before the docking process.

During the docking process, the receptor was rigidly maintained, and the ligands were allowed to flex. The ligand-receptor conformations were generated with docking tolerance at $0.25 \AA$. The conformer fitting was started with a set of several nonpolar or polar hotspots in the receptor was 500. Meanwhile, the ligand-receptor conformations obtained from the docking process were fixed at 500 within the relative energy threshold of 20 . Validation of the docking methods was determined based on the root mean square deviation (RMSD) value from the re-docking process. The RMSD value generated from the re-docking results of the co-crystal ligands to $1 \mathrm{~J} 3 \mathrm{I}$ and $1 \mathrm{~J} 3 \mathrm{~K}$ were 0.6578 and $1.0786 \AA$, respectively.

\section{LIPINSKI’S ‘RULE OF 5' PREDICTION}

Lipinski's rule of five is an empirical rule of thumb to evaluate physicochemical properties and refine drug ability for small molecules. ChemDraw Professional 15.0 software and Sanjeevini web server were utilized to calculate and predict the value of $\log \mathrm{P}$, hydrogen bond donor, and acceptor as well as the molecular weight (Jayaram et al. 2012).

\section{RESULTS AND DISCUSSION}

The QSAR equation model was prepared by selecting the training set (19 compounds) and test set (6 compounds). The QSAR model was generated based on the training set, and the test set performed validation of the model. Before QSAR analysis, the $\mathrm{IC}_{50}$ value was converted into a logarithmic scale to get a better distribution of $\mathrm{IC}_{50}$ value. The net atomic charge (q) of the aminoalkylated chalcone compounds as the electronic descriptor was calculated using the AM1 semi-empirical method, followed by statistical analysis using the Multiple Linear Regression (MLR) backward methods. Principally, the backward method will use all parameters that are used at the beginning of the analysis, and further analysis will eliminate the considered insignificant parameters from the model, and the regression is recalculated. The repetitive step is needed until a simpler model (with the fewest parameters or descriptors) is obtained, but the result must significantly meet the statistical requirements. Based on the statistical analysis using the MLR backward method, the best QSAR model obtained was:

$\log \mathrm{IC}_{50}=705.132(\mathrm{qC} 7)-65.573(\mathrm{qC} 3)-24.845(\mathrm{qC} 4)-$ 4.634 (qC13) - 220.479.

Equation (1) shows a good correlation between descriptors (q) and antimalarial activity (Table 1). The r-value (0.940) indicates that the change of the atomic charges at $\mathrm{C} 3$ (qC3), C4 (qC4), C7 (qC7), and C13 (qC13) atoms from the data set influences $94 \%$ of the antimalarial activity of the chalcone compound. Accuracy of the obtained model to predict the antimalarial activity was also proved by the $\mathrm{F}_{\text {calc }} / \mathrm{F}_{\text {table }}(>1)$ and the PRESS (predictive residual sum of squares) $(<1)$ value.

Validation of the obtained QSAR model is needed to ensure that the model can predict antimalarial activity accurately (Table 2). Validation was performed by plotting the $\log \mathrm{IC}_{50}$ from the experimental against the predicted value (Figure 1 ). The $\mathrm{R}^{2}=0.931$ obtained from the plot suggests that the QSAR model obtained was able to 
predict the experimental antimalarial activity (in vitro) by 93.1\%. Meanwhile, validation of the QSAR model using the test set compounds showed $\mathrm{R}^{2}$ of 0.962 , which means that the model can predict the antimalarial activity quite well. Thus, some chalcone compounds with better antimalarial activity can be proposed based on this QSAR model. In this study, three aminoalkylated chalcone compounds (Figure 2) were proposed for further synthesis and examined theirs in vitro antimalarial activity (Table 3 ).

TABLE 1. Statistical parameters from the Multiple Linear Regression

\begin{tabular}{ccccccc}
\hline \multicolumn{1}{c}{ Variables } & $\mathrm{r}$ & $\mathrm{r}^{2}$ & Adjusted $\mathrm{r}^{2}$ & $\mathrm{SEE}$ & $\mathrm{F}_{\text {calc }} / \mathrm{F}_{\text {table }}$ & PRESS \\
\hline $\begin{array}{l}\mathrm{qC} 3, \mathrm{qC} 4, \mathrm{qC} 7, \\
\mathrm{qC} 13\end{array}$ & 0.940 & 0.883 & 0.824 & 0.300 & 4.40 & 0.659 \\
\hline
\end{tabular}

TABLE 2. Data set compounds, experimental antimalarial activity $\left(\mathrm{IC}_{50}\right)$ (Wilhelm et al. 2015), and predicted $\log \mathrm{IC}_{50}$ using QSAR model

\begin{tabular}{|c|c|c|c|}
\hline Compound & $\mathrm{IC}_{50}$ experiment & $\log \mathrm{IC}_{50}$ experiment & $\log \mathrm{IC}_{50}$ QSAR prediction \\
\hline 1 & 11.30 & 1.053 & 1.145 \\
\hline 2 & 15.71 & 1.196 & 1.168 \\
\hline 3 & 0.83 & -0.081 & 0.009 \\
\hline 4 & 6.54 & 0.816 & 0.841 \\
\hline $5^{\mathrm{a}}$ & 2.81 & 0.449 & 0.550 \\
\hline 6 & 4.90 & 0.690 & 0.699 \\
\hline $7^{\mathrm{a}}$ & 3.77 & 0.576 & 0.531 \\
\hline $8^{\mathrm{a}}$ & 5.75 & 0.760 & 0.672 \\
\hline 9 & 2.74 & 0.438 & 0.663 \\
\hline 10 & 2.52 & 0.401 & -0.210 \\
\hline 11 & 3.10 & 0.491 & 0.556 \\
\hline $12^{\mathrm{a}}$ & 0.17 & -0.770 & -0.327 \\
\hline 13 & 0.15 & -0.824 & -0.704 \\
\hline 14 & 0.14 & -0.854 & -0.773 \\
\hline 15 & 0.10 & -1.000 & -0.759 \\
\hline 16 & 1.37 & 0.137 & 0.150 \\
\hline 17 & 2.42 & 0.384 & 0.478 \\
\hline 18 & 2.73 & 0.436 & 0.282 \\
\hline 19 & 3.10 & 0.491 & 0.230 \\
\hline 21 & 0.19 & -0.721 & -0.612 \\
\hline 24 & 0.21 & -0.678 & -0.102 \\
\hline 25 & 0.06 & -1.222 & -1.002 \\
\hline 26 & 0.01 & -2.000 & -1.879 \\
\hline $27^{\mathrm{a}}$ & 0.07 & -1.155 & -1.009 \\
\hline $28^{\mathrm{a}}$ & 0.09 & -1.046 & -1.001 \\
\hline
\end{tabular}




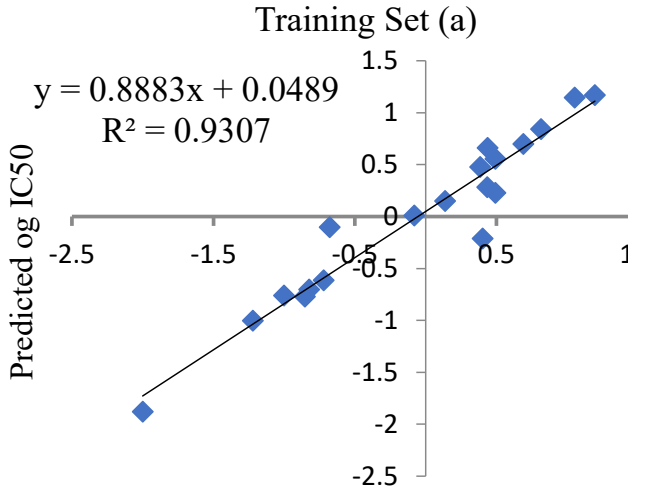

Experimental $\log$ IC50

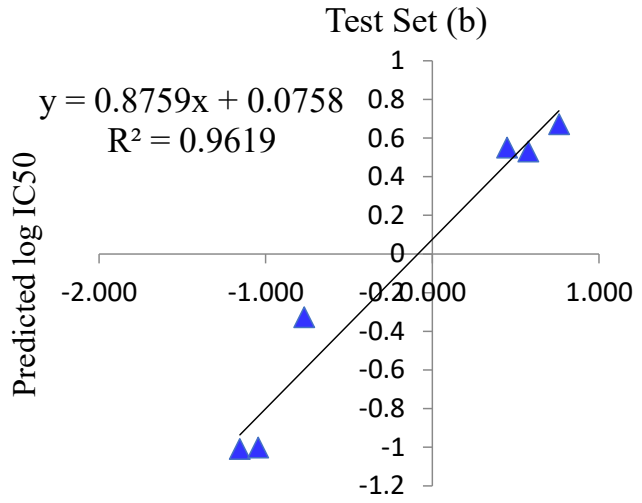

Experimental $\log$ IC50

FIGURE 1. The plot of experimental $\log \mathrm{IC}_{50}$ (in vitro) against predicted $\log \mathrm{IC}_{50}$ from the training set (a) and test set (b) using QSAR model<smiles>COc1cc(/C=C/C(=O)c2ccc(Cl)cc2)cc(CN2CCOCC2)c1O</smiles>

(4a)<smiles>COc1cc(/C=C/C(=O)c2ccc(Cl)cc2)cc(CN2CCCCC2)c1O</smiles>

(4b)<smiles>CCN(CC)Cc1cc(/C=C/C(=O)c2ccc(Cl)cc2)cc(OC)c1O</smiles>

$(4 \mathrm{c})$

FIGURE 2. The synthesized aminoalkylated chalcones (4a-4c) consist of different secondary amines

Three aminoalkylated chalcone compounds (4a-4c) were obtained in good yield by reacting acetophenone derivatives with vanillin via Claisen-Schmidt reaction, followed by the Mannich reaction using formaldehyde and corresponding secondary amines (morpholine, piperidine, and diethylamine) (Figure 2). The synthesized compounds were characterized by ${ }^{1} \mathrm{H}-\mathrm{NMR},{ }^{13} \mathrm{C}-\mathrm{NMR}$, and GCMS, respectively.

The ${ }^{1} \mathrm{H}-\mathrm{NMR}$ spectra of the aminoalkylated chalcone compounds $(4 a-4 c)$ shows the characteristic signals of the resonances of the alkene group with trans conformation at 7.75 and $7.71 \mathrm{ppm}\left(\mathrm{H}_{\alpha}\right.$ and $\left.\mathrm{H}_{\beta}\right)$ with coupling constant of $15.5 \mathrm{~Hz}$. Moreover, there is a singlet peak of an alkyl group (3.7 ppm, $2 \mathrm{H})$ that connects the aromatic ring with the secondary amines. The presence of the downfield signal below 3 ppm signifies the methylene proton and alkyl groups of the secondary amines (morpholine, piperidine, diethylamine), confirming the success of Mannich reaction on the chalcone derivatives. The ${ }^{13} \mathrm{C}-\mathrm{NMR}$ spectrum of compound $4 \mathrm{~b}$ contains a chemical shift of carbon atoms from the carbonyl group (189.4 ppm), $\mathrm{CH}_{3} \mathrm{O}$ (56.2 ppm), and $\mathrm{CH}$ group (61.5 ppm). The $\alpha$ - and $\beta$-carbon atoms that attach to the carbonyl group give characteristic signals between chemical shift $(\delta)$ of 118.9 - 129.9 ppm and 136.9 - 148.5 ppm, respectively.

In vitro antimalarial activity of aminoalkylated chalcone $4 \mathrm{a}-4 \mathrm{c}$ against $3 \mathrm{D} 7$ strain of $P$. falciparum is presented in Table 3. It shows that antimalarial activity $\left(\mathrm{IC}_{50}\right)$ from the predicted and experiments are comparable, based on the order of the compound. The experimental $\mathrm{IC}_{50}$ of the prepared compounds was higher than the predicted calculation. This result was proposed by the difference of the strain that has been used in the assay. The QSAR model was generated from the data set from the 
D10 strain, while during the experimental, 3D7 strain was used. Both the D10 and 3D7 strain of P. falciparum are CQ-sensitive parasite, but it has different gene sequences on the genomic DNA (Cui et al. 2012; Triglia et al. 2001). Nevertheless, the proposed QSAR equation was capable of designing and predicting chalcone-derived compounds that have the best antimalarial activity. The in vitro antimalarial activity of aminoalkylated chalcone $4 \mathrm{a}-4 \mathrm{c}$ was categorized to have an intense activity (Batista et al. 2009), which proposed by the presence of amine groups in chalcone compounds.

TABLE 3. In vitro antimalarial activity of aminoalkylated chalcone, predicted $\mathrm{IC}_{50}$ from QSAR analysis, and CDOCKER energy from molecular docking

\begin{tabular}{lcccc}
\hline & \multicolumn{2}{c}{$\begin{array}{c}\text { Antimalarial activity } \\
\text { Compound }\end{array}$} & \multicolumn{2}{c}{ Molecular docking } \\
\cline { 2 - 5 } & $\begin{array}{c}\text { P. falciparum } \\
\text { (3D7) }\end{array}$ & QSAR & PDB ID 1J3I & PDB ID 1J3K \\
\cline { 2 - 5 } & $0.62 \pm 0.299$ & 0.18 & -49.054 & -49.674 \\
$4 \mathrm{a}$ & $0.54 \pm 0.649$ & 0.15 & -49.230 & -52.374 \\
$4 \mathrm{~b}$ & $1.12 \pm 0.369$ & 0.23 & -48.369 & -49.939 \\
Chloroquine & $0.06 \pm 0.387$ & - & & \\
\hline
\end{tabular}

Molecular docking analysis was performed to find the interaction of the proposed chalcone compound against the CQ-sensitive Plasmodium parasite and also to investigate the potential activity of the proposed compound against the CQ-resistant Plasmodium. Molecular docking of the synthesized compound was carried out on the CQ-sensitive and CQ-resistance dihydrofolate reductases-thymidylate synthase (PfDHFR-TS) protein. PfDHFR-TS protein was chosen as the protein target because it is involved in the inhibition of the production of deoxythymidine monophosphate (dTMP) in the thymidylate cycle of Plasmodium parasite.

Table 3 displays the best CDOCKER docking energy for both CQ-sensitive and CQ-resistance proteins by chalcone $4 \mathrm{~b}$, followed by compounds $4 \mathrm{a}$ and $4 \mathrm{c}$. Notably, the CDOCKER energy of the proposed compound against CQ-resistance protein $(1 \mathrm{~J} 3 \mathrm{~K})$ was lower than the CQsensitive protein (1J3I). It can be seen in Figure 3 that the CQ-resistance protein (1J3K) has formed more hydrogen bonds (green lines) than the CQ-sensitive protein (1J3I). The hydrogen bonds are relatively shorter than phi bonds ( $\pi$, pink line). Thus, hydrogen bonds can build a stronger and stable protein-ligand interaction that is resulting in lower CDOCKER energy. Thus, the proposed compound has the potential to have better in vitro activity against CQ-resistant Plasmodium strains.

Interaction of the prepared chalcone compound $4 \mathrm{a}-4 \mathrm{c}$ to the CQ-sensitive amino acid residue (Figure 3 ) appeared in the form of hydrogen bonds and pi bonds $(\pi)$ with important amino acid residues, such as Ala16, Asp54, Cys15, Leu164, Tyr170, and Met55. Those amino acid residues are an interdomain interaction of co-crystal ligand WR99210 (Yuvaniyama et al. 2003). Generally, the lowest energy and the highest number of hydrogen bonds were formed by compound $4 \mathrm{~b}$, which means chalcone $4 \mathrm{~b}$ has the best antimalarial activity according to the molecular docking result. This docking result supported the outcome of the in vitro antimalarial activity (Table 3 ). The compound $4 \mathrm{~b}$ has displayed some interactions with the amino acid residues of Cys15, Asp54, Phe58, Pro113, Ile164, and Ser108 from the CQ-resistant protein (1J3K). It has been reported that those amino acid residues were the interdomain interaction formed by the co-crystal ligand pyrimethamine (Yuvaniyama et al. 2003).

Based on the molecular docking result in Table 3 and Figure 3, it appears that compound $4 \mathrm{~b}$ has the lowest 
CDOCKER energy and more hydrogen bonds toward the CQ-resistance protein, followed by compounds $4 \mathrm{c}$ and $4 \mathrm{a}$, respectively. The CDOCKER binding energy and the number of hydrogen bonds can determine the strength of the protein-ligand interaction. The lowest CDOCKER energy is more favoured to build the best docking pose of the protein-ligand. Based on these results, chalcone $4 \mathrm{~b}$ was predicted to have a better antimalarial activity to CQ-resistance Plasmodium strains and has the potential to be developed as the lead compound for antimalarial chemotherapy.

Table 4 indicates that all the compounds successfully passed the rule of five (Lipinski et al. 1997), thus, suggesting that the compounds hold the potential of becoming an orally active drug. The increasing number of hydrogen bonds may reduce partitioning from the aqueous phase into the lipid bilayer membrane for permeation by passive diffusion. Furthermore, the compound's molecular mass appeared to be less than 500 Daltons. An increase in molecular weight may reduce the compound concentration at the surface of the intestinal epithelium, hence lessens the absorption. An octanolwater partition coefficient $\log \mathrm{P}$ of the tested compounds also lesser than five, hence preventing poor absorption or permeation (Kalita et al. 2019).

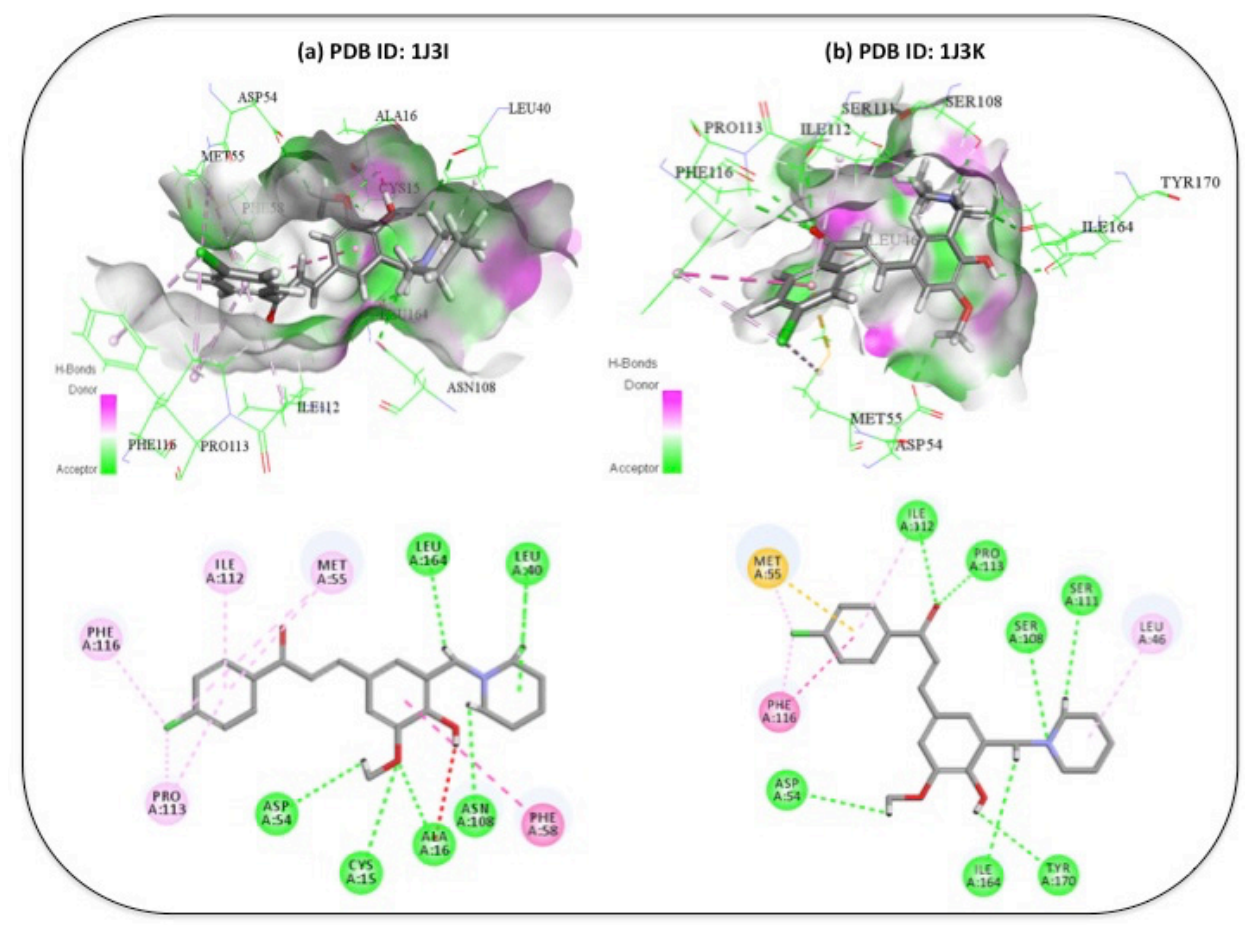

FIGURE 3. 2D and 3D docking pose showing interaction for compound $4 \mathrm{~b}$ in the binding site of a) wild type $P f$-DHFR-TS (PDB ID: 1J3I) and b) mutant type $P f$-DHFR-TS (PDB ID: 1J3K). The colouring atom for the compound is in order as follows: carbons in black, oxygen in red, and hydrogen in white. The green line indicates hydrogen-bonding interaction and the pink line indicates phi-bonding interaction with distance ascribed in angstroms $(\AA)$

TABLE 4. Prediction of Lipinski's 'rule of 5' for tested compounds

\begin{tabular}{lcccc}
\hline $\begin{array}{c}\text { Lipinski rule/ } \\
\text { compounds }\end{array}$ & $\begin{array}{c}\text { Log } \mathrm{p}(\text { lipophilicity) } \\
<5\end{array}$ & $\begin{array}{c}\text { Hydrogen bond } \\
\text { donor }<5\end{array}$ & $\begin{array}{c}\text { Hydrogen bond } \\
\text { acceptor }<10\end{array}$ & $\begin{array}{c}\text { Molecular weight } \\
<500 \mathrm{~g} / \mathrm{mol}\end{array}$ \\
\hline $4 \mathrm{a}$ & 3.78 & 1 & 5 & 387.5 \\
$4 \mathrm{~b}$ & 4.93 & 1 & 4 & 385.5 \\
$4 \mathrm{c}$ & 4.79 & 1 & 4 & 373.5 \\
chloroquine & 4.81 & 1 & 3 & 319.5 \\
\hline
\end{tabular}




\section{CONCLUSION}

In summary, we have reported the design, synthesis, and antimalarial activity evaluation of aminoalkylated chalcone derivatives. The prediction accuracy is given by the developed QSAR model that capable of assessing the $\mathrm{IC}_{50}$ values for antimalarial activity in the experimental measurement. The in vitro evaluation of these derivatives against 3D7 (CQ-sensitive strain) of P. falciparum displayed activity in the $\mu \mathrm{M}$ range. All the compounds showed good interaction with the binding site of $P f$ DHFR-TS and pose acceptable drug-likeliness behaviour favourable for membrane permeability. Cytotoxicity studies of these derivatives are currently underway and shall be published in due course of time.

\section{ACKNOWLEDGEMENTS}

This research was funded by the Deputy of Research and Development Strengthening of the Ministry of Research and Technology/National Agency for Research and Innovation through LLDIKTI Region $\mathrm{X}$ with grant number of 011/LL10/AMD/PG-JL/2020.

\section{REFERENCES}

Ashley, E.A., Dhorda, M., Fairhurst, R.M., Amaratunga, C., Lim, P., Suon, S., Sreng, S., Anderson, J.M., Mao, S., Sam, B., Sopha, C., Chuor, C.M., Nguon, C., Sovannaroth, S., Pukrittayakamee, S., Jittamala, P., Chotivanich, K., Chutasmit, K., Suchatsoonthorn, C., Runcharoen, R., Hien, T.T., ThuyNhien, N.T., Thanh, N.V., Phu, N.H., Htut, Y., Han, K.T., Aye, K.H., Mokuolu, O.A., Olaosebikan, R.R., Folaranmi, O.O., Mayxay, M., Khanthavong, M., Hongvanthong, B., Newton, P.N., Onyamboko, M.A., Fanello, C.I., Tshefu, A.K., Mishra, N., Valecha, N., Phyo, A.P., Nosten, F., Yi, P., Tripura, R., Borrmann, S., Bashraheil, M., Peshu, J., Faiz, M.A., Ghose, A., Hossain, M.A., Samad, R., Rahman, M.R., Hasan, M.M., Islam, A., Miotto, O., Amato, R., Maclnnis, B., Stalker, J., Kwiatkowski, D.P., Bozdech, Z., Jeeyapant, A., Cheah, P.Y., Sakulthaew, T., Chalk, J., Intharabut, B., Silamut, K., Lee, S.J., Vihokhern, B., Kunasol, C., Imwong, M., Tarning, J., Taylor, W.J., Yeung, S., Woodrow, C.J., Flegg, JA, Das, D., Smith, J., Venkatesan, M., Plowe, C.V., Stepniewska, K., Guerin, P.J., Dondorp, A.M., Day, N.P. \& White, N.J. 2014. Spread of artemisinin resistance in Plasmodium falciparum malaria. The New England Journal of Medicine 371(5): 411-423.

Batista, R., de Jesus Silva Júnior, A. \& de Oliveira, A.B. 2009. Plant-derived antimalarial agents: New leads and efficient phytomedicines. part II. non-alkaloidal natural products. Molecules 14(8): 3037-3072.

Bhasin, V.K. \& Nair, L. 2003. ACT now-with caution-for malaria treatments. The Lancet Infectious Diseases 3(10): 609.

Cáceres-Castillo, D., Carballo, R.M., Quijano-Quiñones, R., Mirón-López, G., Graniel-Sabido, M., Moo-Puc, R.E. \& Mena-Rejón, G.J. 2020. Synthesis, in vitro antigiardial activity, SAR analysis and docking study of substituted chalcones. Medicinal Chemistry Research 29(3): 431-441.
Chen, M., Theander, T.G., Christensen, S.B., Hviid, L., Zhai, L. \& Kharazmi, A. 1994. Licochalcone A, a new antimalarial agent, inhibits in vitro growth of the human malaria parasite Plasmodium falciparum and protects mice from P. yoelii infection. Antimicrobial Agents and Chemotherapy 38(7): 1470-1475.

Cui, L., Wang, Z., Miao, J., Miao, M., Chandra, R., Jiang, H., Su, X.Z. \& Cui, L. 2012. Mechanisms of in vitro resistance to dihydroartemisinin in Plasmodium falciparum. Molecular Microbiology 86(1): 111-128.

Dan, W. \& Dai, J. 2020. Recent developments of chalcones as potential antibacterial agents in medicinal chemistry. European Journal of Medicinal Chemistry 187: 111980.

Elkhalifa, D., Siddique, A.B., Qusa, M., Cyprian, F.S., El Sayed, K., Alali, F., Al Moustafa, A.E. \& Khalil, A. 2020. Design, synthesis, and validation of novel nitrogen-based chalcone analogs against triple negative breast cancer. European Journal of Medicinal Chemistry 187: 111954.

Frimayanti, N., Yam, M.L., Lee, H.B., Othman, R., Zain, S.M. \& Rahman, N.A. 2011. Validation of quantitative structureactivity relationship (QSAR) model for photosensitizer activity prediction. International Journal of Molecular Sciences 12(12): 8626-8644.

Golbraikh, A., Shen, M., Xiao, Z., Xiao, Y.D., Lee, K.H. \& Tropsha, A. 2003. Rational selection of training and test sets for the development of validated QSAR models. Journal of Computer-Aided Molecular Design 17(2-4): 241-253.

Jain, S.V., Ghate, M., Bhadoriya, K.S., Bari, S.B., Chaudhari, A. \& Borse, J.S. 2012.2D, 3D-QSAR and docking studies of 1, 2, 3-thiadiazole thioacetanilides analogues as potent HIV-1 non-nucleoside reverse transcriptase inhibitors. Organic and Medicinal Chemistry Letters 2(1): 22.

Jayaram, B., Singh, T., Mukherjee, G., Mathur, A., Shekhar, S. \& Shekhar, V. 2012. Sanjeevini: A freely accessible webserver for target directed lead molecule discovery. $B M C$ Bioinformatics 13: S7.

Jyoti, G.R., Kumar, Y., Cheema, H.S., Kapkoti, D.S., Darokar, M.P., Khan, F. \& Bhakuni, R.S. 2019. Synthesis, molecular modelling studies of indolyl chalcone derivatives and their antimalarial activity evaluation. Natural Product Research DOI: 10.1080/14786419.2019.1696788T.

Kalita, J., Chetia, D. \& Rudrapal, M. 2019. Molecular docking, dug-likeness studies and ADMET prediction of quinoline imines for antimalarial activity. Journal of Medicinal Chemistry and Drug Design 2(1): 1-7.

Khan, S.A., Asiri, A.M., Al-Ghamdi, N.S.M., Asad, M., Zayed, M.E., Elroby, S.A., Aqlan, F.M., Wani, M.Y. \& Sharma, K. 2019. Microwave assisted synthesis of chalcone and its polycyclic heterocyclic analogues as promising antibacterial agents: in vitro, in silico and DFT studies. Journal of Molecular Structure 1190: 77-85.

Lipinski, C.A., Lombardo, F., Dominy, B.W. \& Feeney, P.J. 1997. Experimental and computational approaches to estimate solubility and permeability in drug discovery and development settings. Advanced Drug Delivery Reviews 23(1-3): 3-25.

Modak, V.P., Pathak, H., Thayer, M., Singer, S.J. \& Wyslouzil, B.E. 2013. Experimental evidence for surface freezing in 
supercooled n-alkane nanodroplets. Physical Chemistry Chemical Physics 15(18): 6783-6795.

Motta, L.F. \& Almeida, W.P. 2011. Quantitative structureactivity relationships (QSAR) of a series of ketone derivatives as anti-Candida albicans. International Journal of Drug Discovery 3(2): 100-117.

Quaglio, D., Zhdanovskaya, N., Tobajas, G., Cuartas, V., Balducci, S., Christodoulou, M.S., Fabrizi, G., Gargantilla, M., Priego, E.M., Carmona Pestaña, A. \& Passarella, D. 2019. Chalcones and chalcone-mimetic derivatives as Notch inhibitors in a model of T-cell acute lymphoblastic leukemia. ACS Medicinal Chemistry Letters 10(4): 639-643.

Rammohan, A., Bhaskar, B.V., Venkateswarlu, N., Gu, W. \& Zyryanov, G.V. 2020. Design, synthesis, docking and biological evaluation of chalcones as promising antidiabetic agents. Bioorganic Chemistry 95: 103527.

Rieckmann, K.H., Campbell, G.H., Sax, L.J. \& Ema, J.E. 1978. Drug sensitivity of Plasmodium falciparum: an in-vitro microtechnique. The Lancet 311(8054): 22-23.

Shin, J., Jang, M.G., Park, J.C., Do Koo, Y., Lee, J.Y., Park, K.S., Chung, S.S. \& Park, K. 2018. Antidiabetic effects of trihydroxychalcone derivatives via activation of AMP-activated protein kinase. Journal of Industrial and Engineering Chemistry 60: 177-184.

Sibley, C.H. 2015. Understanding artemisinin resistance. Science 347(6220): 373-374.

Suwito, H., Jumina Mustofa, Pudjiastuti, P., Fanani, M.Z., Kimata-Ariga, Y., Katahira, R., Kawakami, T., Fujiwara, T., Hase, T., Sirat, H.M. \& Puspaningsih, N.N.T. 2014. Design and synthesis of chalcone derivatives as inhibitors of the ferredoxin - ferredoxin-NADP+ reductase interaction of Plasmodium falciparum: Pursuing new antimalarial agents. Molecules 19(12): 21473-21488.

Syahri, J., Yuanita, E., Nurohmah, B.A., Armunanto, R. \& Purwono, B. 2017a. Chalcone analogue as potent antimalarial compounds against Plasmodium falciparum: Synthesis, biological evaluation, and docking simulation study. Asian Pacific Journal of Tropical Biomedicine 7(8): 675-679.

Syahri, J., Rullah, K., Armunanto, R., Yuanita, E., Nurohmah, B.A., Aluwi, M.F.F.M., Wai, L.K. \& Purwono, B. 2017 b. Synthesis, biological evaluation, QSAR analysis, and molecular docking of chalcone derivatives for antimalarial activity. Asian Pacific Journal of Tropical Disease 7(1): 8-13.

Syahri, J., Purwono, B. \& Armunanto, R. 2016. Design of new potential antimalaria compound based on QSAR analysis of chalcone derivatives. International Journal of Pharmaceutical Sciences Review and Research 36(2): 71-76.

Triglia, T., Thompson, J., Caruana, S.R., Delorenzi, M., Speed, T. \& Cowman, A.F. 2001. Identification of proteins from Plasmodium falciparum that are homologous to reticulocyte binding proteins in Plasmodium vivax. Infection and Immunity 69(2): 1084-1092.

Tuncel, S., Trivella, A., Atilla, D., Bennis, K., Savoie, H., Albrieux, F., Delort, L., Billard, H., Dubois, V., Ahsen, V. \& Caldefie-Chézet, F. 2013. Assessing the dual activity of a chalcone-phthalocyanine conjugate: Design, synthesis, and antivascular and photodynamic properties. Molecular Pharmaceutics 10(10): 3706-3716.

Ur-Rashid, H., Xu, Y., Ahmad, N., Muhammad, Y. \& Wang, L. 2019. Promising anti-inflammatory effects of chalcones via inhibition of cyclooxygenase, prostaglandin E2, inducible NO synthase and nuclear factor $\mathrm{\kappa B}$ activities. Bioorganic Chemistry 87: 335-365.

Vinoth, R., Rangarajan, T.M., Singh, R.P. \& Singh, M. 2019. Synthesis of novel chalcones through palladium-catalyzed $\mathrm{CO}$ cross-coupling reaction of bromo-chalcones with ethyl acetohydroxamate and their antiplasmodial evaluation against Plasmodium falcipuram in vitro. Bioorganic Chemistry 86: 631-640.

Wang, J., Huang, L., Cheng, C., Li, G., Xie, J., Shen, M., Chen, Q., Li, W., He, W., Qiu, P. \& Wu, J. 2019a. Design, synthesis and biological evaluation of chalcone analogues with novel dual antioxidant mechanisms as potential anti-ischemic stroke agents. Acta Pharmaceutica Sinica B 9(2): 335-350.

Wang, L., Yang, X., Zhang, Y., Chen, R., Cui, Y. \& Wang, Q. 2019. Anti-inflammatory chalcone-isoflavone dimers and chalcone dimers from Caragana jubata. Journal of Natural Products 82(10): 2761-2767.

Wilhelm, A., Kendrekar, P., Noreljaleel, A.E., Abay, E.T., Bonnet, S.L., Wiesner, L., de Kock, C., Swart, K.J. \& van der Westhuizen, J.H. 2015. Syntheses and in vitro antiplasmodial activity of aminoalkylated chalcones and analogues. Journal of Natural Products 78(8): 1848-1858.

World Health Organization (WHO). 2019 Malaria Vaccines. Geneva, Switzerland: WHO Press.

World Health Organization (WHO). 2018. World Malaria Report. Geneva, Switzerland: WHO Press.

Yang, J.L., Ma, Y.H., Li, Y.H., Zhang, Y.P., Tian, H.C., Huang, Y.C., Li, Y., Chen, W. \& Yang, L.J. 2019. Design, synthesis, and aanticancer activity of novel trimethoxyphenylderived chalcone-benzimidazolium salts. ACS Omega 4(23): 20381-20393.

Yuvaniyama, J., Chitnumsub, P., Kamchonwongpaisan, S., Vanichtanankul, J., Sirawaraporn, W., Taylor, P., Walkinshaw, M.D. \& Yuthavong, Y. 2003. Insights into antifolate resistance from malarial DHFR-TS structures. Nature Structural \& Molecular Biology 10(5): 357-365.

Zhang, J., Zhang, J., Hao, G., Xin, W., Yang, F., Zhu, M. \& Zhou, H. 2019. Design, synthesis, and structure-activity relationship of 7-propanamide benzoxaboroles as potent anticancer agents. Journal of Medicinal Chemistry 62(14): 6765-6784.

Jufrizal Syahri* \& Hasmalina Nasution

Department of Chemistry

Universitas Muhammadiyah Riau

Jalan Tuanku Tambusai Ujung Nomor 1, Pekanbaru Indonesia

Beta Achromi Nurohmah \& Bambang Purwono

Department of Chemistry

Universitas Gadjah Mada

Jalan Kaliurang Sekip Utara Bulaksumur 21

55281, Yogyakarta

Indonesia 
Emmy Yuanita

Department of Chemistry

Universitas Mataram

Jalan Majapahit 62A, Mataram

Indonesia

Nur Hanis Zakaria \& Nurul Izzaty Hassan

Department of Chemical Sciences

Faculty of Science and Technology

Universiti Kebangsaan Malaysia

43600 UKM Bangi, Selangor Darul Ehsan

Malaysia
*Corresponding author; email: jsyachri@umri.ac.id

Received: 10 April 2020

Accepted: 28 May 2020 